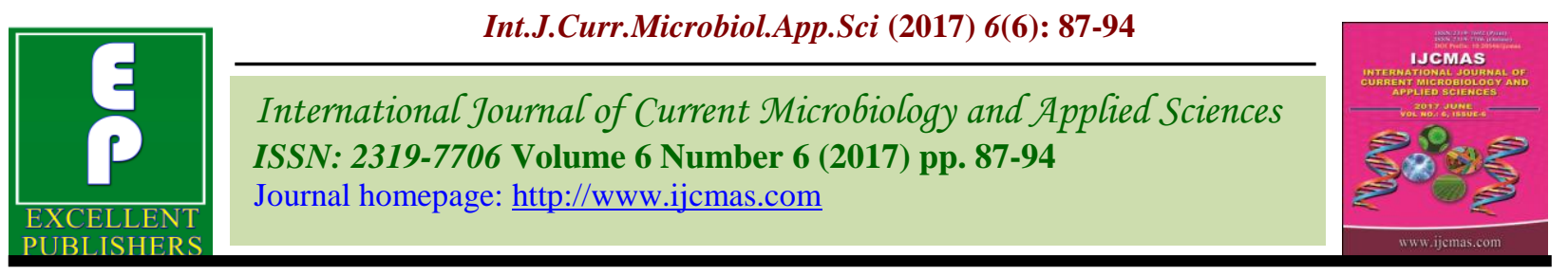

Original Research Article

https://doi.org/10.20546/ijcmas.2017.606.009

\title{
Productivity and Economics of Rice as Influenced by Different Crop Establishment Methods and Weed Management Practices
}

\author{
Y.S. Parameswari ${ }^{*}$ and A. Srinivas \\ Department of Agronomy, College of Agriculture, Professor Jayashankar Telangana State \\ Agricultural University, Hyderabad-500030, India \\ *Corresponding author
}

\section{A B S T R A C T}

\section{Keywords}

Establishment methods, weed management practices, transplanting and yield.

Article Info

Accepted:

04 May 2017

Available Online:

10 June 2017
The influence of different crop establishment methods and weed management practices on productivity and economics of rice was studied at College Farm, College of Agriculture, ANGRAU (Hyderabad) during the kharif season 2010 and 2011 in sandy loam soils. The experiment was laid out in split plot design and replicated thrice with three crop establishment methods i.e. direct sowing of sprouted seeds under puddled condition, SRI and transplanting as main plot treatments and four weed management practices i.e. bensulfuron methyl $60 \mathrm{~g}+$ pretilachlor $600 \mathrm{~g}$ a.i ha ${ }^{-1}$ as pre emergence followed by mechanical weeding at $30 \mathrm{DAS} / \mathrm{T}$, bispyribac sodium @ $25 \mathrm{~g}$ a.i ha ${ }^{-1}$, farmer's practice and weedy check were assigned as subplot treatments. The results revealed that among rice establishment methods, transplanting of rice recorded significantly higher grain yield, straw yield, gross returns and net returns. However, higher B:C ratio was observed with SRI method of establishment. Among weed management practices, higher grain yield, straw yield, gross returns and net returns were registered with farmer's practice however, bensulfuron methyl + pretilachlor mixture @ 60+600 g a.i ha ${ }^{-1}$ followed by mechanical weeding at 30 DAS/T resulted in higher $\mathrm{B}: \mathrm{C}$ ratio.

\section{Introduction}

Rice is one of the most important food grain of the world and staple food of most of the peoples in Asia. Globally rice is cultivated in $154 \mathrm{M}$ ha with an annual production of around 426 million tonnes at an average productivity of $2.76 \mathrm{t} \mathrm{ha}^{-1}$. In India, rice is cultivated round the year in one or the other part of the country, in diverse ecologies spread over $43.8 \mathrm{M}$ ha (Jagtap et al., 2012) with a production of 85.3 million tonnes of rice and the average productivity being $1.94 \mathrm{t}$ $\mathrm{ha}^{-1}$.
Rice is grown mostly under transplanting method in India, though transplanting is popular and successful method the fact is that it is cumbersome and labour intensive practice. The inadequacy of irrigation water and scarce labour coupled with higher wages during the peak period of farm operations, invariably lead to delay in transplanting. To overcome this problem, farmers are gradually switching over to other establishment methods of rice. Weed management is an important key factor in obtaining higher crop 
yield. Weeds compete with crop plants for moisture, nutrients, light, space and other growth factors. Unchecked weed growth causes a reduction in grain yield by about 30$36 \%$ in transplanted rice and $61 \%$ in wet direct seeded rice (Moorthy and Rao, 1991). Sometimes results in complete failure of crop (Pandey et al., 2000) Weed infestation and weed competition are more in direct seeded rice as compared to transplanted rice and SRI because the land is exposed till the initial seedling establishment in direct seeded rice. Hence, timely weed control is necessary to get optimum grain yield. Though manual weeding is considered to be the best, the undependable labour availability and escalating wages in many cases has given impetus to the development and use of chemicals which can control broad spectrum of weeds. The information on weed management in different rice cultures is separately available. However, the information on weed management practices in comparison to different establishment methods. Hence to study the impact of crop establishment methods and weed management practices on productivity and economics of rice, the present investigation was undertaken.

\section{Materials and Methods}

An experiment was conducted during kharif seasons of 2010 and 2011 at College Farm, College of Agriculture, Acharya N.G. Ranga Agricultural University, Hyderabad. The soil was sandy loam with $\mathrm{pH}$ 7.8. The available nitrogen, phosphorus and potassium content in the soil was $234.5,28.9$ and $271.6 \mathrm{~kg} \mathrm{ha}^{-1}$ respectively. The main treatments comprised of three crop establishment methods viz., SRI, Direct sowing of sprouted seeds under puddle condition and transplanting; and four weed management practices in sub plots (bensulfuron-methyl $60 \mathrm{~g}+$ pretilachlor $600 \mathrm{~g}$ a.i $\mathrm{ha}^{-1}$ applied on 3 DAS/T followed by mechanical weeding at $30 \mathrm{DAS} / \mathrm{T}$, bispyribac sodium @ $25 \mathrm{~g}$ a.i ha ${ }^{-1}$ as early post emergence at $15 \mathrm{DAS} / \mathrm{T}$, famer's practice (hand weeding twice at 20 and 40 DAS in direct seeded rice and transplanted rice, conoweeding thrice with 10 days interval from 20 DAT in SRI) and weedy check.

The experiment was laid out in split plot design with three replications. The crop was fertilized with $120 \mathrm{~kg} \mathrm{~N}, 60 \mathrm{~kg} \mathrm{P}_{2} \mathrm{O}_{5}$ and 40 $\mathrm{kg} \mathrm{K}_{2} \mathrm{O} \mathrm{ha}{ }^{-1}$. Half dose of $\mathrm{N}\left(60 \mathrm{~kg} \mathrm{ha}^{-1}\right)$ and full dose of phosphorus (60 kg ha ${ }^{-1}$ ) and potassium (40 kg ha ${ }^{-1}$ ) was applied basal before sowing. The remaining half nitrogen $\left(60 \mathrm{~kg} \mathrm{ha}^{-1}\right)$ was top dressed in two equal splits at tillering and panicle initiation stages. The nursery for transplanting and SRI was sown on the same date of sowing of direct seeded rice during both the years.

\section{Rice establishment}

\section{Direct sowing}

Twenty four hour soaked and 48 hour incubated seeds were sown at $20 \times 10 \mathrm{~cm}$ spacing in the main field designated to direct sowing treatment. After germination of seeds, excess seedlings were thinned out to maintain two seedlings per hill at 15 DAS. Direct sowing and nursery sowing for normal transplanting and system of rice intensification were done simultaneously on same day in both years.

\section{SRI transplanting}

A seed rate of $5 \mathrm{~kg} \mathrm{ha}^{-1}$ was adopted. The sprouted seeds were sown on the mat nursery which was prepared by using the polythene or gunny bags on the shallow raised bed to prevent roots growing deep into the soil. Then 12 days old seedlings were pulled out and planted as single seedlings with a spacing of $25 \times 25 \mathrm{~cm}$. 


\section{Transplanting}

Twenty five day old seedlings were transplanted at $20 \times 10 \mathrm{~cm}$ spacing in leveled plots which were designated to be normal transplanting.

\section{Weed management practices}

Bensulfuron ethyl + pretilachlor mixture $60+$ $600 \mathrm{~g}$ a.i $\mathrm{ha}^{-1}$ was applied at $3 \mathrm{DAS} / \mathrm{T}$ by mixing with sand and followed by a mechanical weeding with push hoe at 30 DAS/T. Bisbyribac sodium @ $25 \mathrm{~g}$ a.i ha ${ }^{-1}$ was applied as early post emergence i.e. when, weeds were at 2-3 leaf stage. A thin film of water is maintained at the time of herbicide application. Farmer's practice comprises hand weeding twice at 20 and 40 $\mathrm{DAS} / \mathrm{T}$ was carried out in normal transplanting and direct seeding of sprouted seeds, conoweeding thrice from 20 DAT with 10 days interval in SRI. The un-weeded control as weedy check was kept undisturbed for the entire cropping period. Weed density and weed dry weight was recorded and their original values transformed using $\sqrt{x}_{\mathrm{x}}+2$ formula.

\section{Results and Discussion}

\section{Effect of crop establishment methods}

The results revealed that transplanting method of establishment gave higher grain yield followed by SRI which was on par with transplanting but significantly superior to direct sown rice under puddled condition. The increase in grain yield recorded under transplanting over SRI and direct sown rice on the onset of monsoon was to the tune of $3.42 \%$ and $13.31 \%$ (mean of two years) respectively. The increased yield attributes might be due to increased growth and development parameters which ultimately resulted in increased grain. The beneficial effect of transplanting method in enhancing the growth through increased height, number of tillers and dry matter production ultimately reflected in higher yield attributing characters viz. number of panicles per $\mathrm{m} 2$, number of grains per panicle number of filled grains per panicle. The present results are in agreement with those of Singh et al., (2006) and Jagtap et al., (2012).

Higher straw yield recorded by transplanting of rice followed by SRI. Transplanting of rice and SRI recorded significantly higher straw yield over direct seeded rice under puddled condition. Increase in straw yield observed under transplanting over SRI and direct sown rice under puddle condition on the onset of monsoon was to the tune of $11.19 \%$ and 3\% respectively. This might be due to increased morphological characters viz., plant height, number of tillers and dry matter production per metre square observed under transplanting. Similar findings were also reported by Ram et al., (2006) and Jagtap et al., (2012).

Among different crop establishment methods, transplanted method of establishment resulted in significantly lower weed density of at all the stages of crop growth and it was comparable to SRI. Significantly higher weed density was observed under direct seeded rice under puddled condition at all the stages of the crop during both years. Continuous submergence of the crop effectively suppressed the weed population and weed seed germination under transplanted rice. Similar observation was reported by Bultazar and De Datta (1992), Bhagat et al., (1999) and Subramanyam et al., (2007). SRI recorded higher weed population per unit area over normal transplanting. Saturated moisture level in SRI plots might have resulted in providing the optimum conditions for weed seed germination and growth compared to submergence in normal transplanting plots 
especially during early stages of growth. In addition to this, the wider spacing in SRI plots might have provided adequate space, nutrients and light availability to weeds especially during the initial stage of crop growth. Similar observations were made by Ceesay and Up off (2003) and Chandrapala (2009). Significantly higher density of weeds was observed in plots where in direct sowing of sprouted seeds was done which could be due to the non-submergence of crop in the initial stages for allowing the sprouts to develop. This condition will be congenial for weed seeds to germinate. The results are in conformity with those of Prakash et al., (1995).

Thus the results clearly showed that transplanting method of establishment was superior which was followed by SRI and direct sown rice. Transplanting of rice gave the highest gross returns (49657 and 57738 $\mathrm{ha}^{-1}$ ) and net returns (25652 and $33733 \mathrm{ha}^{-1}$ ) however, higher $\mathrm{B}: \mathrm{C}$ ratio was observed under SRI due to low cost of cultivation followed by transplanting of rice (Table 1). Similar findings were also reported by Chadrapala (2009) and Hugar et al., (2009).

\section{Effect of weed management practices}

The important weeds observed in cropped area were Cynodon dactylon, Panicum sps. Cyperus rotundus, Cyperus iria, Cyperus difformis, Echinochloa colonum, Ammania baccifera and Eclipta alba. The grain yield of rice was significantly influenced by weed management practices.

Table.1 Gross returns, net returns and B:C ratio of rice as influenced by different establishment methods and weed management practices in rice

\begin{tabular}{|c|c|c|c|c|c|c|}
\hline \multirow{2}{*}{$\begin{array}{l}\text { Treatments } \\
\text { Main treatments }\end{array}$} & \multicolumn{2}{|c|}{ Gross returns ( $\left(\mathrm{fha}^{-1}\right)$} & \multicolumn{2}{|c|}{ Net returns ( $\left(\bar{\gamma} \mathrm{ha}^{-1}\right)$} & \multicolumn{2}{|c|}{ B: C ratio } \\
\hline & 2010 & 2011 & 2010 & 2011 & 2010 & 2011 \\
\hline SRI & 48017 & 55903 & 25587 & 33473 & 2.14 & 2.49 \\
\hline Direct sown rice & 43883 & 51424 & 20808 & 28349 & 1.90 & 2.23 \\
\hline Transplanting & 49657 & 57738 & 25652 & 33733 & 2.07 & 2.41 \\
\hline \multicolumn{7}{|l|}{ Sub treatments } \\
\hline $\begin{array}{l}\text { Bensulfuron methyl + } \\
\text { Pretilachlor followed by } \\
\text { mechanical weeding at } 30 \\
\text { DAS/T }\end{array}$ & 59749 & 69870 & 36871 & 46992 & 2.61 & 3.05 \\
\hline Bispyribac sodium & 44776 & 52514 & 21908 & 29646 & 1.96 & 2.30 \\
\hline Farmer's practice & 62771 & 73238 & 36903 & 47370 & 2.43 & 2.83 \\
\hline Weedy check & 25447 & 26464 & 4379 & 5396 & 1.21 & 1.26 \\
\hline
\end{tabular}


Table.2 Weed density, weed dry matter, grain yield and straw yield $\left(\mathrm{kg} \mathrm{ha}^{-1}\right)$ of rice as influenced by different treatments

\begin{tabular}{|c|c|c|c|c|c|c|c|c|}
\hline \multirow{2}{*}{$\begin{array}{l}\text { Treatments } \\
\text { Main treatments }\end{array}$} & \multicolumn{2}{|c|}{ Weed density $\left(\mathrm{m}^{-2}\right)$} & \multicolumn{2}{|c|}{ Weed dry weight $\left(\mathrm{g} \mathrm{m}^{-2}\right)$} & \multicolumn{2}{|c|}{ Grain yield(kg ha $\left.{ }^{-1}\right)$} & \multicolumn{2}{|c|}{ Straw yield $\left(\mathrm{kg} \mathrm{ha}^{-1}\right)$} \\
\hline & 2010 & 2011 & 2010 & 2011 & 2010 & 2011 & 2010 & 2011 \\
\hline SRI & $8.14(64.48)$ & $7.69(57.43)$ & $6.29(37.67)$ & $5.97(33.67)$ & 4265 & 4438 & 5364 & 5697 \\
\hline Direct sown rice & $8.81(75.63)$ & $8.30(66.69)$ & $6.75(43.49)$ & $6.44(39.47)$ & 3894 & 4075 & 4948 & 5300 \\
\hline Transplanting & $7.68(57.00)$ & $7.23(52.62)$ & $5.98(33.73)$ & $5.85(32.20)$ & 4408 & 4593 & 5579 & 5811 \\
\hline SEm \pm & 0.17 & 0.15 & 0.12 & 0.10 & 91 & 90 & 99 & 97 \\
\hline $\mathrm{CD}(0.05)$ & 0.66 & 0.60 & 0.45 & 0.41 & 356 & 354 & 387 & 381 \\
\hline \multicolumn{9}{|l|}{ Sub treatments } \\
\hline $\begin{array}{l}\text { Bensulfuron methyl }+ \\
\text { Pretilachlor followed by } \\
\text { mechanical weeding at } 30 \\
\text { DAS/T }\end{array}$ & $6.06(34.68)$ & $5.78(31.45)$ & $4.16(15.32)$ & $3.72(11.86)$ & 5326 & 5585 & 6489 & 6824 \\
\hline Bispyribac sodium & $8.48(69.92)$ & $7.92(60.80)$ & $5.84(32.13)$ & $5.57(29.06)$ & 3975 & 4158 & 5023 & 5433 \\
\hline Farmer's practice & $5.60(29.31)$ & $5.26(25.65)$ & $3.64(11.25)$ & $3.28(8.74)$ & 5601 & 5857 & 6766 & 7134 \\
\hline Weedy check & $11.44(128.92)$ & $10.94(117.73)$ & 9.82(94.48) & $9.63(90.78)$ & 1854 & 1874 & 2911 & 3019 \\
\hline SEm \pm & 0.17 & 0.21 & 0.18 & 0.19 & 95 & 107 & 106 & 109 \\
\hline $\mathrm{CD}(0.05)$ & 0.50 & 0.64 & 0.54 & 0.57 & 283 & 318 & 316 & 323 \\
\hline \multicolumn{9}{|l|}{ Interaction } \\
\hline $\mathrm{SEm} \pm(\mathrm{M} \times \mathrm{S})$ & 0.29 & 0.37 & 0.31 & 0.34 & 165 & 185 & 184 & 188 \\
\hline $\mathrm{CD}(0.05)$ & NS & NS & NS & NS & NS & NS & NS & NS \\
\hline $\mathrm{SEm} \pm(\mathrm{S} \times \mathrm{M})$ & 0.34 & 0.33 & 0.29 & 0.31 & 177 & 182 & 194 & 193 \\
\hline $\mathrm{CD}(0.05)$ & NS & NS & NS & NS & NS & NS & NS & NS \\
\hline
\end{tabular}


Among all weed management practices, farmer's practice registered higher grain yield which was on par with application of bensulfuron methyl $60 \mathrm{~g}+$ pretilachlor $600 \mathrm{~g}$ a.i ha ${ }^{-1}$ followed by mechanical weeding at $30 \mathrm{DAS} / \mathrm{T}$. The higher grain yield with both the treatments is due to decreased weed competition and minimum nutrient removal by weeds which might have increased the capacity of nutrient uptake and enhanced the source and sink sizes which in turn increased the yield attributes viz., panicle number per hill, panicle length and filled grains per panicle. Saha and Rao et al., (2010) and Sunil et al., (2010) found similar type of findings in their study.

The straw yield of rice followed similar trend like grain yield. The maximum straw yield of rice recorded under farmer's practice and it was on par with bensulfuron methyl $60 \mathrm{~g}+$ pretilachlor $600 \mathrm{~g}$ a.i ha $^{-1}$ followed by mechanical weeding at 30 DAS/T. Higher straw yield was attributed to weed management treatments provided conducive environment and enhanced the growth of rice crop which in turn was reflected in terms of straw yield. These results are in confirmation with the findings of Mukherjee and Singh (2005) and Sanjay et al., (2006).

Bispyribac sodium recorded significantly lower straw yield than the other two weed control measures. Weedy check recorded significantly lower straw yield during both the years. Farmer's practice recorded higher gross returns and net returns followed by bensulfuron methyl $60 \mathrm{~g}+$ pretilachlor $600 \mathrm{~g}$ a.i ha ${ }^{-1}$ followed by mechanical weeding at 30 DAS/T. However, higher B:C ratio was observed under bensulfuron methyl $60 \mathrm{~g}+$ pretilachlor $600 \mathrm{~g}$ a.i $\mathrm{ha}^{-1}$ followed by mechanical weeding at $30 \mathrm{DAS} / \mathrm{T}$ due to low cost of cultivation. Similar findings were also reported by Uma (2012).
During both the years, weed management practices in rice significantly lowered weed density at all the stages compared to weedy check. Among weed management practices, farmer's practice registered significantly lower weed density at all the stages. However, it was significantly superior to all the weed management practices only at 30 DAS, but it was comparable at 60, 90 DAS and at harvest with bensulfuron methyl $60 \mathrm{~g}$ a.i + pretilachlor $600 \mathrm{~g}$ a.i $\mathrm{ha}^{-1} \mathrm{fb}$ mechanical weeding at $30 \mathrm{DAS} / \mathrm{T}$. This could be due to regular removal of broad spectrum of weeds in hand weeding twice. Similar observations were reported by Laxminarayana and Mishra, (2001), and Avudailhai and Veerabadran (2000). Similarly, Sunil et al., (2010) noticed that pre emergence application of bensulfuron methyl + pretilachlor $0.06+0.60 \mathrm{~kg} \mathrm{ha}^{-1}$ and one intercultivation at 40 DAS recorded significantly lower weed density. Bispyribac sodium@25 g a.i ha ${ }^{-1}$ was found inferior in controlling weeds against the other two methods of weed management but remained significantly lower weed density over weedy check (Table 2).

Pre- emergence application of bensulfuron methyl $60 \mathrm{~g}$ a.i + pretilachlor $600 \mathrm{~g}$ a.i ha ${ }^{-1}$ $\mathrm{fb}$ mechanical weeding at $30 \mathrm{DAS} / \mathrm{T}$ registered the highest $\mathrm{B}: \mathrm{C}$ (2.61 and 3.05) ratio than other weed management practices.

\section{Interaction effects between crop establishment methods and weed management practices}

None of the growth characters and yield attributes was markedly influenced by interaction effects of crop establishment methods and weed management practices. Similarly grain and straw yields were also not influenced by interaction effects between crop establishment methods and weed management practices. 
From the results, it can be concluded that to get higher B: C ratio crop should be established by SRI and weeds should be managed by bensulfuron methyl $60 \mathrm{~g}+$ pretilachlor $600 \mathrm{~g}$ a.i $\mathrm{ha}^{-1}$ followed by mechanical weeding at $30 \mathrm{DAS} / \mathrm{T}$ compared to other methods of establishment and weed management practices.

\section{References}

Avudailhai, S., and Veerabadran, V. 2000. Effect of herbicide mixtures on total weed spectrum in transplanted rice. Crop Research. 19 (1): 16-22.

Bhagat, R.M., Bhuiyan, S.I., and Moody, K. 1999. Water, tillage and weed management options for wet seeded rice in Phillipines. Soil and Tillage Research. 51-58.

Bultazar, A.M., and De Datta, S.K. 1992. Weedmanagement in rice. Weed abstract. 41, 495-508.

Ceesay, M., and Up off, N. 2003. The effect of repeated soil wetting and drying on lowland rice yield with system of rice intensification (SRI) methods. In: http:/ciifad.cornell.edu/.

Chandrapala, A.G., 2009. Productivity of rice-maize cropping system as influenced by crop establishment methods and nutrient management ( $\mathrm{S}$ and Zn). Ph.D thesis submitted to Achraya N.G. Ranga Agricultural University.

Hugar, A.Y., Chandrappa, H., Jayadeva, H.M., Satish, A., and G. B. Mallikarjun, 2009. Influence of different establishment methods on yield and economics of rice. Agriculture Science Digest 29 (3): 202-205.

Jagtap, D.N., Mahadkar, U.V., and L.S. Chavan, 2012. Productivity and economics of rice influenced by different crop establishment methods and fertilizer sources. Agricultural Journal 7 (1): 32-36.

Laxminarayana, P., and Mishra, B. N. 2001. Effect of nutrient and weed management practices on weeds and yield of transplanted rice (Oryza sativa L.). Annals of Agricultural Research. New Series 22 (2): 258-261.

Moorthy, B.T.S., and Rao, K.S. 1991. Influence of method of stand establishment and cultural and weed control practices on performance of rainfed lowland rice in coastal Orissa. Indian Journal of Agricultural Sciences. 61: 588-590.

Mukherjee, D., and Singh, R.P. 2005b. Effect of micro-herbicides on weed dynamics, yield and economics of transplanted rice. Indian Journal of Agronomy. 50 (40): 292-295.

Panday, A.K., Prakash, V., Singh,P., Prasad, K., Singh, R.D., and Mani, V.P, 2000. Weed management in major crops of north-western Himalyas. Technical Bulletin 16, p.66. VPKAS, Almora.

Prakash, P., Nanjappa, H.V., and Ramchandrappa, B.K. 1995. Chemical weed control in direct seeded puddled rice. Crop Research. 9 (2): 197-202.

Ram, M., OM, H., Dhiman, S.D., and D.P. Nandal, 2006. Productivity and economics of rice (Oryza sativa)wheat (Triticum aestivum) cropping system as affected by establishment methods and tillage practices. Indian Journal of Agrononomy 51(2): 77-80.

Saha, S., and K.S. Rao, 2010. Evaluation of Bensulfuron-methyl for weed control in wet direct-sown summer rice. Oryza 47 (1): 38-41.

Sanjay, M.T., Shetty, T.K.P., and H.V. Nanjappa, 2006. Enhancing productivity of rice under different crop establishment methods through weed management practices. Crop Research 31 (2): 192-197. 
Singh, V.P., Singh, G., Singh, S.P., Kumar, A., Sharma, G., Singh, M.K., Mortimer, M., and D.E. Johnson, 2006. Effect of weed management and crop establishment methods on weed dynamics and grain yield of rice. Indian Journal of Weed Science 38 (1\&2): $20-24$.

Singh, V.P., Singh, G., Singh, S.P., Kumar, A., Sharma, G., Singh, M.K., Mortimer, M., and Johnson, D.E. 2006. Effect of weed management and crop establishment methods on weed dynamics and grain yield of rice. Indian Journal of Weed Science. 38 (1\&2): $20-24$.

Subramanyam, D., Raghava Reddy, C., and Srinivasulu Reddy. 2007. Influence of

\section{How to cite this article:}

Parameswari, Y.S. and Srinivas, A. 2017. Productivity and Economics of Rice as Influenced by Different Crop Establishment Methods and Weed Management Practices. Int.J.Curr.Microbiol.App.Sci. 6(6): 87-94. doi: https://doi.org/10.20546/ijcmas.2017.606.009 